\title{
Literary Nationalism in Indonesia: Modern literature and its Development
}

\author{
Ismet Fanany \\ Professor of Language and Society \\ Deakin University \\ ismet.fanany@deakin.edu.au
}

\begin{abstract}
The concept of nationalism has frequently been used to classify and analyze a range of cultural expressions, including literature. For the newer nations of the world, it has been discussed in the context of the post-colonial experience as one of the themes commonly discernable in the modern literature of the nation in question. Indonesia falls into this category; nationalism has been viewed by scholars as an important element in some of its modern literature. This paper considers the way nationalism has been identified and interpreted in modern Indonesian literature and draws parallels from the experience of the United States which is also discussed. It concludes that Indonesian literature displays a similar type of literary nationalism and that this is a more accurate classification than the distinction of certain nationalist works or authors.
\end{abstract}

Keywords-- Indonesian literature, nationalism, 20th century

\section{INTRODUCTION}

Nationalism, as a concept, focuses on the collective experience of a particular nation and may emerge as an ideology, a sentiment, a culture, or even a social movement. Historians generally agree that the concept of nationalism arose in $18^{\text {th }}$ century Europe and was a major contributing cause of both World War I and World War II. In a broad sense, nationalism is a complex of ideas that associate basic political, moral, and cultural values with nation and nationality (Miscevic, 2008).

Not surprisingly, nationalism has frequently been a force in cultural expression and specifically in literature where it has served to elucidate such concepts as national character, national attitudes, and national actions, where "national" refers to those attributes seen at the time as being characteristic or emblematic of the citizenry in question. In understanding this phenomenon in the literature of any nation, there is value in considering the literature of the United States, which has perhaps produced the largest body of modern literature and has also generated the most study and criticism.

American literary nationalism has generally been based on a period often referred to as the "American Renaissance," which centered on the writers of New York and New England in the mid-19th century. These writers, who included Ralph Waldo Emerson (1803-1882), Henry David Thoreau (1817-1862), Nathaniel Hawthorne (1804-1864), Herman Melville (1819-1891), and Walt Whitman (1819-1892), were viewed as having adopted the main principles of European Romanticism and adapted them to what was still, at the time, a new nation. By 1855, each of them had contributed to what came to be seen as an American national canon (Matthieson, 1941).

More recently, however, other American writers who did not belong to this group of writers have been identified as also contributing to the documentation of the American experience. This group includes women, African American, Native American, and immigrant authors, and it is now generally recognized that American literary nationalism is not only complex but incorporates many different strains. While the authors discussed by Matthieson are still central to the development of American literary identity, American literature is no longer seen as merely an effort to distance the American experience from that of England. Rather, it is viewed as an illustration of American identity as multiple, contested, and unsettled in the period leading up to the Civil War (1860-1864).

Philosopher and poet Ralph Waldo Emerson was the major figure in the American Renaissance in his calls for a national literature. His essays, such as "Nature" (1836), "The American Scholar" (1837), and "Self-Reliance" (1841), describe the main aspects of American identity and call for writers to represent them. Emerson stressed the need for a national literature that celebrated the individualism, democracy, and equality that he viewed as lying at the center of American life. Emerson's own writing represented a specific type of nationalism. His transcendentalism centered on the expansion of the self at a time when the United States was promoting westward expansion and the concept of Manifest Destiny. Emerson's aim of spiritual occupation of the American nation reflects the contemporaneous political understanding of the relationship between the American population and its land (Matthieson, 1941).

For Emerson, the reliance on European tradition and history rather than self-reliance was un-American. The next generation of writers addressed this dilemma, each in his own way. Henry David Thoreau, for example, like Emerson, believed in the centrality of nature to the construction of individual and national identity. But, where Emerson's writing was 
extremely broad, Thoreau focused on detail and attempted to demonstrate an idealized concept of "simplicity" in contrast to the economically driven lifestyle he observed around him. Thoreau also directly addressed political causes in a manner not attempted by Emerson; he viewed the concept of government as contrary to American identity which was based on individual action arising from principle (Matthieson, 1941).

Walt Whitman concerned himself as much with form as content. Whitman's poetry represents an effort to unite the nation during the lead-up to the Civil War. His use of varying form mirrors the diversity of people and experience in the United States. His claim in Leaves of Grass (1855), "I am large . . I contain multitudes," can be seen as a commentary on his verse form as well as on the relationship between the poetic "I" and the nation. Whitman revised Leaves of Grass several times allowing for expansion and incorporation of new ideas and new people, just like the American nation (Matthieson, 1968).

Nathaniel Hawthorne also considered how American should write as well as what the content of that writing should be. In his own work, he addressed issues like self-reliance, class, the legacy of Puritanism, and the relationship of the individual to the community. His works also represent a meta-narrative concerning the most appropriate way to tell the national story. Hawthorne believed that his America could only be understood through its history, and most of his works take place in the $17^{\text {th }}$ century, an allegory for events contemporary to him that were taking place in the $19^{\text {th }}$. "The Custom House", which serves as an introduction to The Scarlet Letter (1850) describes the laziness of Hawthorne's co-workers, which he contrasts with the energy and willingness to act of their Puritan forefathers. While Hawthorne criticized many of the characteristics of the Puritans (their lack of imagination and intolerance, for example), he viewed them as a positive alternative to what he saw as the societal decay around him. In fact, he justified his use of history in his writing by claiming that his world was dull and unimaginative (Matthieson, 1941).

Of the writers of the American Renaissance, Herman Melville is the most problematic. His works were not widely read during his own lifetime and were not viewed as effective by those contemporary critics who read them. In the $20^{\text {th }}$ century, however, Melville's works, and especially Moby Dick (1851), took on new significance as Ishmael (the narrator in Moby Dick) was seen to embody American freedom in contrast to the totalitarianism of Captain Ahab. Nonetheless, Melville's writing, like Emerson's, reflects a sense of national crisis, and, like Thoreau's, suggests that the nation had deviated from the ideals embodied in the Constitution and reflects his sense of despair (Matthieson, 1941).

The idea that transcendentalism (in the style of the American Renaissance) represented a benchmark in American cultural identity was largely unchallenged until the 1970 s. Until that time, even the most popular writers of the $19^{\text {th }}$ century, Washington Irving (1783-1859), James Fenimore Cooper (1789-1851), Henry Wadsworth Longfellow (1807-1882), James Russell Lowe (1819-1891), and John Greenleaf Whittier (1807-1892), were generally overlooked. Their national narratives were viewed as conforming to European norms, despite the fact that Longfellow's poems embody Native American legends and Whittier's support the abolitionist cause. These were specifically American issues but were addressed by the authors in ways that could be traced to European ideas of Romanticism (Adams, 1952).

Women were originally excluded from the national canon because it was assumed their lives were confined to the home and their identity constructed accordingly. The writers of the American Renaissance themselves contributed to this view. After her death, Emerson spent a great deal of time undermining the reputation of Margaret Fuller (1810-1850), a leading transcendentalist. Hawthorne and Melville mocked the success of female writing whose works were generally much more commercially successful. Later critics accepted almost implicitly that the public, political sphere was more important than the writing of female authors (Tompkins, 1985).

Now, however, it is accepted that the works of sentimental fiction by writers like Harriet Beecher Stowe (18111896), Susan Warner (1819-1885), and Fanny Fern (Sarah Payson Willis Parton, 1811-1872) are as important as those of Hawthorne and Melville in the formation of an American literature. Stowe's Uncle Tom's Cabin, for example, illustrates how the American public is straying from its proper course and warning of the consequences if it does not return to its correct direction. The novel is addressed to a female readership who is encouraged to see the nation from a female perspective and to use their view to change the nation's cultural identity. The novel, like many others, is an example of the extent to which women did, in fact, participate in public debate over national identity, the causes of suffrage and abolition, debates over Indian removal, and Manifest Destiny (Kaplan, 2002).

Recent criticism has also demonstrated the importance of African American narratives in forming the American canon through writing that both embraces and subverts the themes of individualism and self-reliance. The presence of elements of African folklore has been shown in works of white writers like Melville as well (Sundquist, 1993; Rowe, 1997). Specifically, a process of exchange between European American literature and African American literature has been noted (Sundquist, 1993), as has the influence of the political writings of individuals like Frederick Douglass (1818-1895) and Harriet Jacobs (c1813-1897) on the formation of national identity (Rowe, 1997). It is now clear that there are significant 
literary traditions inherent to women, African American, and other writers in America and that these traditions are integral to American literary nationalism.

The development of American literature can be seen as an effort to establish a unique identity that distinguished its authors and audience from those in Europe, the region of origin for a large majority of Americans. Many of the ideas that were current in $18^{\text {th }}$ and $19^{\text {th }}$ century America, the period in which its national literature took form, can be traced to similar concepts that had emerged in Europe during the same period. This relationship is at the base of the criticism of Longfellow, Lowe, and others noted above. However, American literature from its earliest period contained elements that derived specifically from its own context and experience, first as part of the larger English-speaking sphere and later as a multilayered society incorporating many groups with their own cultural and literary traditions.

\section{METHOD}

The term post-colonial tends to be associated with the new nations of the developing world that gained independence following World War II. In principle, however, because the term simply means "after colonial experience," some authors have suggested the term be expanded to include all English language writing in societies affected by colonialism. Under this conceptualization, the literature of the United States must be considered post-colonial. Ashcroft et al $(1989$, p. 2) characterized this post-colonial literature as follows:

...the literatures of African countries, Australia, Bangladesh, Canada, Caribbean countries, India, Malaysia, Malta, New Zealand, Pakistan, Singapore, South Pacific Island countries, and Sri Lanka are all post-colonial literatures. The literature of the USA should also be placed in this category. Perhaps because of its current position of power, and the neo-colonizing role it has played, its postcolonial nature has not been generally recognized. But its relationship with the metropolitan centre as it evolved over the last two centuries has been paradigmatic for post-colonial literature everywhere. What each of these literatures has in common beyond their special and distinctive regional characteristics is that they emerged in their present form out of the experience of colonization and asserted themselves by foregrounding the tension with the imperial power, and by emphasizing their differences from the assumptions of the imperial centre. It is this which makes them distinctively post-colonial.

This view suggests that the development of American literature may provide a useful model for the consideration of other literatures. The large size of the canon as well as the nation's rise to prominence may be an indication of the potential exposure of other writers to American ideas in literature as well as the availability of these ideas as models or paradigms (see Buell, 1992, for discussion of this issue). Additionally, the concept of post-colonial literature developed from American scholarship and critique (Edwards and Tredell, 2008).

Not surprisingly therefore, the discussion of nationalism in post-colonial literature is well-established. Most of the writers in regions that were formerly European colonies contributed to the development of literatures that position themselves as weapons against colonial cultural imposition. Indonesia was not immune to this tendency; nationalism in Indonesian literature has typically been considered as having two periods of nationalism, before World War II and after independence.

\section{FINDING AND DISCUSSION}

Nationalist sentiment is widely viewed to have emerged in Indonesia in the first half of the $20^{\text {th }}$ century and is often associated with such figures as R. A. Kartini, M. Hatta, and St. Sjahrir, and political movements like Boedi Oetomo, Sukarno's Perserikatan Nasional Indonesia, and Sarekat Islam. Indonesia's early novels, many written by individuals whose origins lay in the pan-Malay tradition, frequently addressed issues like the relationship between Indonesians and Dutch, the role and abuse of adat and traditional privileges accorded to the elite, and the place of young Indonesians in the larger international sphere and hence can be seen as embodying strong elements of nationalism in their aim of describing the emerging national character in opposition to the Dutch colonial entity.

The early literature of Indonesia has been discussed in the context of nationalism by such authors as Teeuw, Anderson, and others, but it is perhaps the nation's literature since independence that is more significant in the current context and certainly for its role in forming the modern self-conception of today's Indonesians. In 1975, HB Jassin considered Indonesian literature to be firmly ensconced in world literary tradition (Jassin, 1983). Nonetheless, outside of Indonesia and apart from a few specialists interested in its literature in the west, very little is known about its content. Garcia (2006, p. 184) noted that the nation is:

“... better known for ... volcanoes, island paradises, shadow puppets, and the world's largest population of Muslims, Indonesia's books remain largely untranslated, a secret library ringed by fire and water." 
The works of Pramoedya Ananta Toer, which are probably the most widely known Indonesian works available in translation, are almost always viewed in relation to anti-colonialism and nationalistic ideology, rather than in the context of world literature (Day, 2006). By contrast, it is important to consider how modern Indonesian literature functions in the explication of the themes and ideas that defined Indonesian society through the $20^{\text {th }}$ century and how it reacted to a series of events in Indonesia, not solely in the context of colonialism and its end.

Teeuw's writing on modern Indonesian literature serves as the base for much of the current interpretation of $20^{\text {th }}$ century literary production in the nation. Teeuw (1994) suggests that a nationalist spirit in Indonesian literature is tied to the use of the Indonesian language (or Indonesian variant of Malay in its early days) and began to be visible around 1915, following the establishment of Balai Pustaka in 1908. He categorizes the novels of this period as "pre-nationalist" (1994, p. 60 ) and places them in the context of political events. The themes of these early works, such as Sitti Nurbaya (by Marah Rusli, 1922), Salah Pilih (by Nur Sutan Iskandar, 1928), and Pertemuan (by St Pamuntjak, 1927) among others, according to Teeuw, center on the conflict between generations and specifically the challenge to adat posed by outside influences which, in the case of these novels, originated in the colonial establishment and seemed to offer a choice to the novels' characters. Seen in this light, Teeuw notes that Pertemuan presents the idea that happiness can only be found by remaining true to one's traditional culture, in this case the Minangkabau spirit (1994, p. 59). Teeuw reviews a number of other prewar novels which he considers to fit into basically the same pattern; the characters experience elements of a "modern" lifestyle (education, social interaction, work) and attempt with varying degrees of success to reconcile their experience with their traditional way of life. Novels with a religious theme, such as those of Hamka (Karena Fitnah (1938), Merantau ke Deli (1939), for example), Teeuw dismisses as moralistic, psychologically weak, and melodramatic (1994, p. 72), although he does concede their popularity.

Teeuw's views on early Indonesian literature influenced many other writers on the subject (see, for example, Johns, 1959; Sutherland, 1968; Thomas et al, 1985; Fitzpatrick, 2000, and many others both in and outside of Indonesia) but do not sufficiently account for the depth of these early novels. While it is possible to say that they center on a conflict of generations, represented by the positioning of adat against modernity, it is important to recognize that the writers of this generation did not present a traditional way of life as a panacea for the ills of (then) modern life; they tended, in fact, to be quite critical of the social and familial restrictions placed on individuals by traditional mores. Teeuw and others acknowledge this but conceive the situation as a dichotomy between adat, on the one hand, and westernized life, on the other. In fact, it is possible to understand these early Indonesian novels as expressing a desire for a third way that would allow individuals to escape the restrictive nature of tradition and also preclude imitating the ways of the Dutch. The dilemma of the characters of these early novels, such as Hanafi in Salah Asuhan, is that neither traditional life nor westernized existence in the colonial realm brings them satisfaction.

In this, these early novels should be considered nationalist (not prenationalist, as Teeuw suggests). They represent the desire of the Indonesian public for a form of society and culture that is specific to them, a desire that parallels the goals of the writers of the American Renaissance discussed above. In this context, religious themed novels must not be dismissed as melodramatic and poorly written (see Teeuw, 1994, p. 72). Rather, they must be seen as embodying a significant aspiration of the contemporary public to have religion play an important role in their society. It is this that accounts for their popularity, not an inexplicable interest in novels of this kind by Muslims, as Teeuw suggests. The parallel with writers like Ralph Waldo Emerson, who was a Unitarian minister and who called for a re-establishment and renewal of Christianity appropriate for the new American nation, cannot be ignored (see Emerson, 1982). It is also important to understand the role of the experience of specific ethnic groups in contributing to the explication of nationalist sentiment in Indonesian literature. It has been acknowledged that the national sphere in Indonesia is constructed from the nation's diversity from its independence (the national motto, Bhinneka tunggal ika, states this explicitly). For this reason, the collective understanding and interpretation of the experience of Indonesia's many cultrally and linguistically defined communities should be seen as being directly related to the search for nationalism in literature.

Nationalism in Indonesian literature continued to be expressed and, after the earliest period described above, is next associated with the Poejangga Baroe writers, a term which refers to the literary magazine where many of them published their work. These individuals, a number of whom were poets, are often credited with first conceptualizing a cultural identity for Indonesia, in addition to its political identity that emerged earlier (Foulcher, 1980). Poejangga Baroe itself, as a literary vehicle, is credited with providing a forum for the development of the modern Indonesian language and literary conventions free from the restrictions of Balai Pustaka, which was limited in the subject matter it was willing to publish (Teeuw, 1994). Led by the writings of Sutan Takdir Alisjahbana, the Poejangga Baroe writers engaged in debate and explication of the nature of culture, the most important element of which, in the context of literary nationalism, was the idea that the past was gone, and a new Indonesian nation could only be built by looking to the future (see AK Mihardja, ed, 1998). Again, looking to the American experience for comparison, the future as the proper milieu for a new Indonesian 
society is comparable to the concept of Manifest Destiny in America as a guiding aspiration and direction in building a national literature.

Once independent, the quest for a nationalist literature in Indonesia was not without its exclusions, instances where writers or works were shunned because of a perceived divergence in theme or content that did not fit with the general conception of Indonesia as embodied in literary works. This came most notably in the form of the Manifesto Kebudayaaan (Manikebu), which appeared on August 17, 1963, and represented a rejection of extreme left wing views in literature espoused by the writers associated with the Lembaga Kebudayaan Rakyat (Lekra), who were viewed as Communists using their writing as a vehicle for political propaganda (see Foulcher, 1969; Chambert-Loir, 1972; among others). As the Indonesian cultural mainstream rejected Communism as a literary inspiration, the leaders of the American Renaissance rejected support for the institution of slavery, accepting only an abolitionist outlook as a component of national literature. It is for this reason that the works of writers such as Edgar Allan Poe (1809-1849), who was seen as anti-abolitionist even though his writings did not address this issue, are considered only in the context of genre development and not part of the American national literary canon (Matthieson, 1941).

Skipping ahead in time to the present day, Indonesia has evolved into a modern nation of a form likely unimagined by the early nationalist writers. Having gone through several political stages that contributed to the concerns and ideas of nation expressed by the writers of the times, Regional Autonomy has become the political and administrative structure providing form to current society and an organizing feature of all forms of culture. The period of Regional Autonomy, now more than a decade old since its original conceptualization, has allowed regionalism to flourish in many forms (see, for example, Yuwono, 2003; Laksmi, 2006), not excluding literature.

The literature of this period has been characterized by a greater emphasis on the experience of particular Indonesian ethnic groups in specific locations within the nation. A very clear example of this is the very popular Laskar Pelangi by Andrea Hirata that appeared in 2005. A portrayal of the life story of one individual, this novel and its sequels offers a detailed explication of a modern life unfolding from the island of Belitung to encompass Indonesia at large and the international world beyond. Unlike the early novels described above where it is possible to identify the main characters with all Indonesians or any single Indonesian of the time, Laskar Pelangi portrays the development of one group, emphasized early in the first volume through a discussion of names. In describing the employees of the tin mining corporation in his town, the main character notes:

Orang-orang yang tinggal di dalamnya memiliki nama-nama yang aneh, mislanya Susilo, Cokro, Ivonne, Setiawan, atau Kuntoro, tak ada Muas, Jamali, Sa'idun, Ramli, atau Mahader seperti nama-nama orang Melayu, dan mereka tidak pernah menggunakan bin atau binti (p. 42).

[The people who lived inside had strange names like Susilo, Cokro, Ivonne, Setiawan, or Kuntoro. There was no Muas, Jamali, Sa'idun, Ramli, or Mahader, names the Malay used, and they never used bin or binti.]

The reader easily recognizes the "strange" names as those originating in other parts of Indonesia; this device very clearly illustrates that we are to view the people of Belitung as separate from the rest of the nation, representing a particular cultural entity. The novels are, in fact, very inward looking to the specific and intimate details of the perceptions and world view of this group, despite their broad setting and stand in contrast to the universalist nature of Indonesia's early novels where, regardless of where they take place and the ethnic origin of their characters, the main figures attempt to live beyond their immediate surroundings in the search for a new reality.

The Laskar Pelangi novels are only one example of a regional focus in recent literature and represent only one manifestation of this phenomenon. The novel Bulan Susut (2006) by this writer presents another, where the main character's interaction with the institutions of modern Indonesia are intended only to enhance his position in his ethnic (Minangkabau) society, and there are others as well. Interestingly, where early Indonesian novels sought freedom from adat and the limitations of traditional society, current novels tend to seek the constancy of ethnic identity. This is perhaps in line with an international trend toward group identification (see, for example, Finegan and Rickford, 2004; Belluscio, 2006).

If we wish to draw a further parallel with the literature of the United States, we might suggest that the current trend towards the expression of ethnicity in the context of Indonesian literature is similar to the Local Color period in American literature. This type of literature became popular after the Civil War and is usually associated with the period from 1865 to the turn of the $20^{\text {th }}$ century. This type of literature focuses on characters, customs, dialects, and other features common in one part of the nation only and that are readily identifiable with that location. Mark Twain is perhaps the best known writer of this movement, although many others, including Hamlin Garland, Joel Chandler Harris, Mary Austin and Bret Harte, fall into this category. The Oxford Companion to American Literature notes: 
In local-color literature one finds the dual influence of romanticism and realism, since the author frequently looks away from ordinary life to distant lands, strange customs, or exotic scenes, but retains through minute detail a sense of fidelity and accuracy of description. Its weaknesses may include nostalgia or sentimentality (p. 439).

This brief characterization fits well with Indonesian works like Laskar Pelangi, which is, in fact, a highly romanticized portrayal of the main character's experience seen through the lens of the particular culture of his region of origin. It is likely that the popularity of the series, disproportionate to its literary skill, is a reaction to the novels' ability to serve this need; in other words, these novels appeared at the right moment to fulfill a certain aspiration felt across Indonesia to reconcile ethnic experience with national identity. In the US, local color came about as a response to the Civil War which shocked the public and led to major changes in administration and the ways in which the nation was viewed. In this, it parallels the inception of Regional Autonomy in Indonesia, which can be seen as the shock factor that has served to change public outlook. The function of local color literature in the US has been described as follows by Brodhead (1993):

Regionalism's representation of vernacular cultures as enclaves of tradition insulated from larger cultural contact is palpably a fiction . . . its public function was not just to mourn lost cultures but to purvey a certain story of contemporary cultures and of the relations among them (p. 121).

In the US, this period in literature contributed to the developing narrative about national unity and nationhood that began to emerge following the Civil War and led to the type of literature focusing largely on the individual and his psychology that characterized the twentieth century. It is not unreasonable to suggest that the same needs that drove American literature before and after the Civil War are replicated in Indonesia, beginning in the early $20^{\text {th }}$ century and extending through its post-colonial period to the present day. In this context, we might understand the freedom seeking literature of the pre-independence period and the politically influenced nationalist literature that appeared immediately before and in the period after independence as making up the formative base of a modern literary nationalism, with more recent developments centering on local experience functioning as a means to discern the common threads that join the narratives of a very diverse nation. It is interesting to note that one of these threads that runs through Indonesian literature from the early $20^{\text {th }}$ century up to the present, is that of religion.

\section{CONCLUSION}

In considering the relationship between nationalism and literature, it is appropriate to briefly consider terminology. In the US, the need for a national literature began almost as soon as the Declaration of Independence was signed in 1776, and the debate about what this might be continued for some 75 years. Two issues surfaced as part of this discussion: first, what would be the materials of an American literature and what should be the spirit and purpose of American writers; and second, the creation of an American literature and what it should contain (Frederick, 1959). "Literary nationalism" was considered a worthy goal for the new nation, and the resulting literature, as described above, came to encompass many voices representing America's ethnic make-up and regional composition. In the early $20^{\text {th }}$ century, the national literature expanded again to absorb a multitude of immigrant stories that contributed to the modern conceptualization of the state and its literature (see, for example, Payant, 1999). "Nationalist literature," which is characterized by a political motivation as opposed to purely literary aims, has never been popular in the US but is a feature of a number of nations whose recent experience centered on the (artificial) creation of broadly accepted conception of nationhood by political leaders (see, for example, Landau, 2003, on Turkey; Fulton, 1998, on Korea; Miller, 1993, on various African nations; Hughes, 2005, on China; and many others). Indonesia, despite political and historical similarities with some of these nations, already possesses a literature that has more in common with that of the United States as discussed here. For this reason, it is perhaps appropriate that we adopt the idea of "literary nationalism," as opposed to "nationalist literature" or nationalism in literature," that is wide enough to encompass all the writing that is created by Indonesians and makes use of the Indonesian language as a unifying feature of our shared experience. This conceptualization is broad enough to embrace dialect use, local color, a variety of literary goals, and a range of voices that more properly reflects the diversity of the nation and allows for the blending of individual perception into a national experience. More important, such a conceptualization will allow for the future expansion of Indonesian literature without the limitations imposed by rigid canonical definitions, without selfimposed inhibitions on the part of writers, and without impediment to the greater exploration of the Indonesian psyche. 


\section{References}

Adams, R. P. (1952). "Romanticism and the American Renaissance" in American Literature, 23 (4). 419-432.

Ashcroft, B., Griffiths, G., \& Tiffin, H. (1989). The Empire Writes Back: Theory and Practice in Post-Colonial Literatures. London: Routledge.

Belluscio, S. J. (2006). To be suddenly white: Literary realism and sudden passing. Colombia, MO: University of Missouri Press.

Brodhead, R. H. (1993). Cultures of letters: Scenes of reading and writing in nineteenth century america. Chicago: The University of Chicago Press.

Buell, L. (1992). "American Literary Emergence as a Postcolonial Phenomenon" in American Literary History, 4 (3). 411 442.

Chambert-Loir, H. (1972). "Horison: six annees d'une revue litteraire Indonesienne" in Archipel, 4 (4). 81-89.

Day, T. (2006). "Locating Indonesian Literature in the World" in Modern Language Quarterly, 68. 173-193.

Edwards, J. D., \& Tredell, N. (2008). Postcolonial literature. Basingstoke, UK: Palgrave Macmillan.

Emerson, R.W. (1982). Selected essays and addresses, Ziff, L, ed. New York: Penguin.

Finegan, E., \& Rickford, J.R. eds. (2004). Language in America: Themes for the $21^{\text {st }}$ century. Cambridge, UK: Cambridge University Press..

Fitzpatrick, E.B. (2000) "Balai Pustaka in the Dutch East Indies: Colonizing a Literature," in Simon, S. and St Pierre, P., eds, Changing the Terms: Translating in the Post-Colonial Era, Ottawa: University of Ottawa Press. 113-126.

Foulcher, K. (1969). "A Survey of Events Surrounding Manikebu: The Struggle for Cultural and Intellectual Freedom in Indonesian Literature" in Bijdragen tot de Taal-, Land- en Volkenkunde, 125 (4). 429-465.

Foulcher, K. (1980). Pujangga baru literature and nationalism in Indonesia, 1933-1942. Adelaide, SA: Flinders University Asian Studies Monograph No 2.

Frederick, J. T. (1959). "American Literary Nationalism: The Process of Definition, 1825-1850" in Review of Politics, 21 (1) $224-238$.

Fulton, B. (1998). "Kijich'on Fiction," in Pai, H.I. and Tangherlini, T.R., eds, Nationalism and the Construction of Korean Identity. Berkeley, CA: University of California Press, Berkeley, CA. 13-32.

Garcia, M. N. (2006). "Indonesian Publishing: New Freedoms, Old Worries, and Unfinished Democratic Reform" in Social Analysis 50 (1). 184-191.

Hart, J. D. (1995). The oxford companion to american literature. New York: Oxford University Press.

Hughes, C. R. (2005). "Interpreting Nationalist Texts: A Post-Structuralist Approach" in Journal of Contemporary China, 14 (43). 247-267.

Jassin, H. B. (1983). Sastra Indonesia sebagai Warga Sastra Dunia dan Karangan-karangan Lain. Jakarta: Gramedia.

Johns, A. H. (1959). "Indonesian Literature and Social Upheaval" in Australian Journal of International Affairs. 13 (4). 293-303.

Kaplan, A. (2002). The Anarchy of Empire in the Making of US Culture. Cambridge, MA: Harvard University Press.

Laksmi, B. I. (2006). Proses Pelapukan: Tantangan Indonesia Merdeka. Jakarta: Penerbit Buku Kompas.

Landau, J. M. (2003). "Ultra-Nationalist Literature in the Turkish Republic: A Note on the Novels of Huseyin Nihal Atsiz" in Middle Eastern Studies, 39: 2 pp. 204-210.

Matthieson, F.O. (1941). American renaissance: Art and expression in the age of Emerson and Whitman. London and New York: Oxford University Press.

Matthiessen, F.O. (1968). American renaissance: Art and expression in the age of Emerson and Whitman: Art and Expression in the Age of Emerson and Whitman. Oxford, UK: Oxford University Press.

Mihardja, A.K., ed. (1998). Polemik kebudayaan. Jakarta: Balai Pustaka.

Miller, C.K.L. (1993). "Nationalism as Resistance and Resistance to Nationalism in the Literature of Francophone Africa" in Yale French Studies 82: 1 pp. 62-100.

Miscevic, N. (2008). "Nationalism" in Zalta, E.N., ed. The Stanford Encyclopedia of Philosophy (Fall 2008 Edition), URL $=<\mathrm{http}: / /$ plato.stanford.edu/archives/fall2008/entries/nationalism/ $/$.

Payant, K.B. (1999). The immigrant experience in north american literature: Carving Out a Niche. New York: Praeger.

Rowe, J.C. (1997). At Emerson's Tomb: The Politics of Classic American Literature. New York: Columbia University Press.

Ruben, P. (2009). Perspectives in American Literature. $<$ http://www.csustan.edu/english/reuben/pal/TABLE.HTML $>$.

Sundquist, E.J. (1993). To Wake the Nations: Race in the Making of American Literature Cambridge, MA: Harvard University Press. 
Sutherland, H. (1968). Pudjangga Baru: Aspects of Indonesian Intellectual Life in the 1930s. Southeast Asia Program Publications, Cornel University, Ithaca, NY.

Thomas, P. L. et al., (1985). "'State of the Art' Surveys: Indonesian Literature" in Asian Studies Review, 9 (1). 19-32.

Tompkins, J. (1985). Sensational Designs: The Cultural Work of American Fiction, 1790-1860, New York: Oxford University Press.

Yuwono, T. (2003). "Quo Vadis Otonomi Daerah di Indonesia?" in Suara Merdeka, October 9, 2003. $<$ http://www.suaramerdeka.com/harian/0310/09/kha2.htm>. 